\title{
Law to keep labels off genes
}

\section{Washington}

FEARs that discrimination against those at risk of developing genetic disorders will be a malign result of increasing knowledge about the human genome have prompted a bill introduced last week by Representative John Conyers (Democrat, Michigan).

The Human Genome Privacy Act, the first of its kind anywhere, promises to give individuals the right to privacy on information about their genetic make-up. Discrimination based on an individual's genetic diagnosis and screening records would be prohibited in areas such as employment, insurance and education.

Cases of 'genetic discrimination' have already been documented.According to Paul Billings, vice chairman of the department of medicine at the Pacific Presbyterian Hospital in San Francisco and a prominent supporter of the Privacy Act, individuals have been denied health insurance and employment because they were known from genetic evidence to have disorders such as Charcot-MarieTooth muscular atrophy and the neurodegenerative disorder Friedrich's Ataxia.

Asymptomatic carriers of recessively inherited disorders including sickle-cell anaemia and Gaucher disease, a disorder of lipid metabolism, have also been refused employment because of misguided fears that they themselves were susceptible to the disease.

The new act would prevent the disclosure of genetic information by government agencies, contractors or grantrecipients without an individual's written consent. Exceptions would be made in cases of medical emergency and criminal investigation. Conyers, chairman of the government operations committee, has won widespread backing within the scientific and religious communities for the legislation and expects bipartisan support in Congress.

Long-time adversaries Jeremy Rifkin, president of the Foundation on Economic Trends, and W. French Anderson, a leading researcher into gene therapy at the National Institutes of Health (NIH), both find themselves backing the initiative.

Rifkin hopes the act will serve as a model for similar legislation soon to be introduced in about 20 countries, mainly in Europe. Although the proposed US legislation applies only to government agencies and their affiliates, "it is important that government establishes the standard by which private industry will then respond", Rifkin said last week at a press conference held to launch the act.

Anderson was also expected to speak at last week's press conference, but withdrew at the last minute because the Department of Health and Human Services "denied me permission to go as an NIH scientist", he said. Nevertheless, Anderson affirmed that he "strongly supports the concept behind the bill" and its introduction as a "means of initiating public discussion".

Billings says that "the variability of genetic disorders and the fact that some of them are not particularly severe are not appreciated by the general public or by the people who are making policy decisions for employers, insurers or even adoption agencies". Congessional hearings of the Human Genome Privacy Act will begin next spring.

Kevin Davies \& Dlane Gershon SUPERCOMPUTERS

\section{London centre in funding row}

\section{London}

ONE of Britain's three academic supercomputing centres may be forced to cut back its services, because of a dispute between the Department of Education and Science (DES) and the University of London over the centre's funding. The DES Computer Board has told the University of London that funding for the University of London Computing Centre (ULCC)'s Cray supercomputer must be reduced from almost $£ 2$ million to $£ 1$ million a year, but the university is reluctant to foot the bill. The board also wants to cut funding for the centre's smaller Amdahl computer by almost $£ 900,000$.

Together with a similar-sized centre at the University of Manchester and the larger Atlas facility at the Science and Engineering Research Council's Rutherford Appleton Laboratory (RAL), ULCC provides a national supercomputing service for the UK academic community. But ULCC currently costs DES about twice as much to run as the Manchester centre.

ULCC's actual operating costs differ little from those in Manchester - both run a large supercomputer and a second-string machine. But the Manchester centre is run as a local computing facility for the university. This means that the university can run the national service at 'marginal cost', simply charging DES for the extra staff, software and maintenance needed to supplement the local service. ULCC, by contrast, is separate from the computing centres at each of London's colleges, so the bulk of its running costs fall to DES.

Professor John Forty, chairman of the Computer Board and principal of the University of Stirling, says that ULCC's costs are "abnormally high" and must be brought down "in the national interest". But this means that the University of London must take on more of the centre's

\section{University of democracy Paris}

Авоuт 40 Chinese students attended last week the 'Summer University of Democracy' in Paris. For one week the students were able to hear talks on different aspects of democratic civilization given by a dozen leading academics, mostly specialists in law and economics, and Jiaqi Yan, a dissident and former adviser to the Chinese Prime Minister.

The 'university' was financed from funds raised by the French Ministry of Culture on the initiative of the Maison Chinoise pour la Democracie, which was set up in June 1989 as a focus for efforts to establish democracy in China, following the Tianenmen Square massacre.

Peter Coles

running costs or accept cutbacks. Faced with an accumulating financial deficit (predicted to rise more than $£ 40$ million by 1992-93), the university is likely to take a tough line, not least because contributing more to ULCC's running costs would set a dangerous precedent for the other national facilities hosted by London.

London's federal structure also makes it difficult to link ULCC with one of the university's other computing centres and run it as a University of London service with the national service provided at marginal cost. The other centres are attached to individual London colleges and are not provided for the university as a whole.

The Computer Board is expected to make a final decision on ULCC's future funding in October. If the University of London refuses to take more of the load, the board will consider switching some work to the other two national supercomputing centres. But Brian Davies, head of computing at RAL, says "the slack couldn't be taken up on the machine we've got". Professor Frank Sumner, director of computing at Manchester, says the Manchester machines would need upgrading to absorb extra work.

The drive to cut costs in British academic supercomputing contrasts with expanding capacity in other countries. Sumner says that British academics were "far better provided for" than their US colleagues six years ago, but investment in new facilities by the National Science Foundation means the United States is now "way ahead".

Expansion is also under way in West Germany, with the German company Siemens installing new machines in Karlsruhe, Aachen and Hanover over the next six months. German academics benefit from the desire of each of the Länder to host a state-of-the-art supercomputing centre, with regional government putting up half of the cost of each.
Peter Aldhous 